\title{
A practical study on the feasibility of alpha and gamma-tocopherol quantification for distinguishing Iberian pig feeding systems
}

\author{
By A.I. Rey ${ }^{1, *}$, D. Amazán ${ }^{1}$ and J. García-Casco ${ }^{2}$ \\ ${ }^{1}$ Dpto. Producción Animal, Facultad de Veterinaria, Universidad Complutense de Madrid, Spain \\ ${ }^{2}$ Centro de investigación del Cerdo Ibérico, Zafra, Badajoz, Spain \\ * Corresponding author: anarey@vet.ucm.es
}

\section{RESUMEN}

Estudio práctico de la fiabilidad de la cuantificación de alfa y gamma-tocoferol para diferenciar los sistemas de alimentación del cerdo ibérico

Este estudio se llevó a cabo para comprobar la fiabilidad del uso de la cuantificación de alfa y gamma-tocoferol en grasa y músculo para establecer una clasificación correcta de los cerdos ibéricos de acuerdo a su alimentación. Las muestras se obtuvieron durante tres campañas diferentes procedentes de cuatro categorías de cerdos según se describe en la norma de calidad (FREE-OUT: «bellota», FREEOUT-FEED: «recebo», FEED-OUT: «campo» y FEED-IN «cebo»). Se calcularon funciones discriminantes con los datos obtenidos de las campañas 1 y 2 y se validaron. La clasificación de las muestras de grasa y músculo obtenidas de la tercera campaña en las cuatro categorías de acuerdo a las funciones discriminantes calculadas alcanzó un rango medio de éxito del $76 \%$ para diferenciar el origen de las muestras. La cuantificación en el músculo pareció tener una mayor capacidad de predicción. Las ecuaciones de regresión para cuantificar el peso ganado en montanera en función de la concentración de gamma-tocoferol tuvieron un mayor $\mathrm{R}^{2} \mathrm{pa}$ ra el músculo que para la grasa $\left(R^{2}=0.81\right.$ vs. 0.62$)$. La unión de alguna de las categorías de alimentación establecidas en la norma de calidad podría incrementar la fiabilidad del método de cuantificación de los tocoferoles alfa y gamma hasta entre un 89 al $98 \%$.

PALABRAS CLAVE: Alfa-tocoferol - Cerdo ibérico - Diferenciación de la alimentación - Gamma-tocoferol.

\section{SUMMARY}

A practical study on the feasibility of alpha and gamma-tocopherol quantification for distinguishing Iberian pig feeding systems

This study was undertaken to test the feasibility of using alpha and gamma-tocopherol quantification in fat and muscle to establish a correct classification of Iberian pigs according to their feeding background in practical situations. Samples were obtained over three different seasons from the four categories of pigs described in the Industry Quality Policy (FREE-OUT "bellota"; FREE-OUT-FEED "recebo"; FEEDOUT "campo"; and FEED-IN "cebo"). Linear discriminant functions were calculated with data obtained from seasons 1 and 2 and validated. The classification of fat and muscle samples from season 3 in the four feeding categories according to the calculated discriminant functions achieved an average of $76 \%$ success rate in distinguishing the true origin of pig samples. Quantification in muscle seemed to have higher prediction ability. Regression equations to quantify weight gained depending on the gamma-tocopherol concentration had higher $R^{2}$ values for muscle than for fat $\left(R^{2}=0.81\right.$ vs. 0.62$)$. Merging of the feeding categories established by the Quality Policy could raise the accuracy of the alpha and gamma-tocopherol quantification method to up to between $89 \%$ and $98 \%$.

KEY-WORDS: Alpha-tocopherol - Feeding distinguishing - Gamma-tocopherol - Iberian pig.

\section{INTRODUCTION}

The Iberian pig, an autochthonous breed mainly reared in the southwest of Spain, is known for the high quality and commercial value of its products. Products from lberian pigs reared in a free-range production system and fed on natural resources (mainly acorns and grass) reach the highest quality and prices (López-Bote, 1998; García et al., 1996) and are characterized by having high levels of oleic acid (Rey et al., 2006a) and antioxidants such as tocopherols (Rey et al., 2006b, Tejerina et al., 2012) and other compounds (Cantos et al., 2003) provided by acorn and grass consumption (Rey et al., 1998; Tejerina et al., 2011). If the amount of acorns and grass is not enough to cover feeding requirements because of climatic conditions, pigs can be supplemented with feeds that result in a loss in quality (López-Bote, 1998).

To prevent fraud and to properly identify the feeding background of the animals, quality control practices such as the fatty acid analysis of adipose tissue by gas chromatography have been widely used (BOE, 2001). However, this method has been recently devalued (BOE, 2007) because of the incorrect classification of pigs fed in intensive conditions with an oleic acid-enriched mixed diet as those that had been fed in freerange conditions. Consequently, during the last few years much effort has been invested to finding new methods to differentiate Iberian pigs according to feeding type. One of the possibilities studied has been the quantification of alpha and gammatocopherols. Hence, in a previous study, Rey et al. (2006a) reported that pigs raised free-ranged showed higher gamma-tocopherol concentration 
in muscle and subcutaneous fat than pigs fed a formulated diet in confinement. In an additional experiment, these authors (Rey et al., 2006b) found a direct relationship between gamma-tocopherol accumulation and time of free-range feeding and weight gained outdoors, which suggests that this could be used as a discriminator for different pig meat qualities. However, this study was carried out under standard conditions. Taking into account the heterogeneity of Iberian pig production, which is similar to other outdoor-reared based systems (Pugliese and Sirtori, 2012), more research is needed to evaluate the feasibility of tocopherol quantifications in practical situations.

The objectives of the present study were first to quantify isomers (alpha- and gamma-tocopherol) in subcutaneous fat and Longissimus dorsi muscle from Iberian pigs fed in different commercial feeding situations; and second, to study the feasibility of tocopherol (alpha- and gamma-) quantification for differentiating and establishing a correct classification according to feeding background in practical situations.

\section{MATERIALS AND METHODS}

\subsection{Samples}

Samples (subcutaneous fat and Longissimus dorsi muscle) were obtained from Iberian pigs raised in controlled feeding conditions in three different seasons: 2008-2009, 2009-2010 and 20102011. During the 2008-2009 season, fat $(n=180)$ and muscle samples $(n=188)$ were collected from the following feeding groups: (1) FREE-OUT: pigs raised in free-range conditions and exclusively fed acorns and grass (they put on at least $46 \mathrm{~kg}$ or 4 arrobas) in the ever-green oak forest in different geographical areas (Salamanca and Badajoz, Spain) (fat $n=61$; muscle $n=57$ ) (known as "bellota" according to BOE, 2007); (2) FREE-OUT-FEED: pigs raised in free-range conditions and fed acorns and grass (they put on at least $29 \mathrm{~kg}$ or 2,5 arrobas in free-range conditions) and also with a mixed diet during the fattening phase (fat $n=12$; muscle $n=12$ ) (known as "recebo"); (3) FEED-OUT: pigs fed either a conventional diet (fat $n=62$; muscle $n=62$ ) or a fat-enriched diet: (fat $n=13$; muscle $n=25$ ) and with access to grass (known as "campo"); (4) FEED-IN: pigs fattened with a standard commercial pig diet (fat $n=32$; muscle $n=32$ ) (known as "cebo").

During the $2009-2010$ season fat $(n=205)$ and muscle samples $(n=205)$ were obtained according to the following feeding system: (1) FREE-OUT: $\mathrm{n}=55$; (2) FREE-OUT-FEED: pigs raised in freerange conditions that received feed either at the end of the fattening phase or throughout the fattening period $(n=50) ;(3)$ FEED-OUT: $n=75$; FEED-IN: $n=25$.

During the 2010-2011 season, fat $(n=336)$ and muscle $(n=164)$ samples were collected from very different farms according to the following distribution: (1) FREE-OUT: fat $n=135$; muscle $n=$ 45; (2) FREE-OUT-FEED: fat $n=74$; muscle $n=25$; (3) FEED-OUT: fat $n=47$; muscle $n=38$; (4) FEEDIN: fat $n=80 ;$ muscle $n=56$.

Pigs from the first two seasons were raised in controlled farms or experimental institutions (Valdesequera, Badajoz, Spain), which had implemented a traceability system and a periodic inspection program. Pigs from the last season were raised in practical quality control conditions and they came from a wide variety of farms.

Animals were stunned and slaughtered at a live weight of approximately $152.5( \pm 3.7 \mathrm{~kg})$ and samples of subcutaneous fat were obtained from the tail insertion area in the coxal region and kept frozen at $-20^{\circ} \mathrm{C}$ until analysis. Additionally, a small piece of muscle (Longissimus dorsi) was taken and kept in the same conditions.

Classification was performed according to the tocopherol levels on blind samples so that the feeding group was unknown at the time of analysis.

\subsection{Laboratory Analysis}

\subsubsection{Alpha and Gamma-Tocopherol Quantification}

Concentrations of alpha- and gamma- tocopherols in muscle (Longissimus dorsi), were quantified by the direct method described by Rey et al. (1996) without previous saponification. Muscle samples $(0.8 \mathrm{~g})$ were homogenized in a $0.054 \mathrm{M}$ dibasic sodium phosphate buffer adjusted to $\mathrm{pH} 7.0$ with $\mathrm{HCl}$. After mixing with absolute ethanol and hexane, the upper layer containing tocopherol was evaporated to dryness and dissolved in $200 \mu \mathrm{L}$ ethanol prior to analysis by reverse phase HPLC (Agilent 1100, Agilent Technologies, Waldbronn, Germany). Separation was carried out on an Agilent Technologies Lichrospher RP-C18 column (250 $\mathrm{mm} \times 4 \mathrm{~mm}$ i.d., $5 \mu \mathrm{m}$ particle size), the mobile phase was methanol/water $(97: 3 \mathrm{v} / \mathrm{v})$ at a flow rate of $2 \mathrm{ml} / \mathrm{min}$ and peaks were recorded at $292 \mathrm{~nm}$. The identification and quantification of both tocopherols was carried out by means of a standard curve $\left(R^{2}=0.9999\right)$ developed with the pure compounds (Sigma, Alcobendas, Madrid). Results were expressed as $\mu \mathrm{g}$ of alpha-tocopherol or gamma-tocopherol per $\mathrm{g}$ of fresh matter.

Tocopherols in subcutaneous fat were quantified as described by Rey et al. (2006b) in which samples were saponified in the presence of $\mathrm{KCl}(1.15 \%)$ and $\mathrm{KOH}(50 \%)$. Tocopherols were extracted with hexane and the upper layer was evaporated and dissolved in ethanol prior to analysis by reverse phase HPLC (HP 1100, provided with a diode array and fluorescence detector) (Agilent Technologies, Waldbronn, Germany). Analysis by HPLC was carried out following the same procedure described before with the exception that peaks were detected by a fluorescence detector (Agilent technologies series 1200) set at $\lambda$-excitation: $295 \mathrm{~nm}$ and $\lambda$-emission: $330 \mathrm{~nm}$. 
Samples were assayed in duplicated for both analyses (muscle and fat). Recovery of gammatocopherol was not lower than $80 \%$ and the internal standard (alpha-tocopheryl acetate) was added.

\subsection{Statistical Analysis}

The data were analyzed as a completely randomized design using the general linear model (GLM) procedure contained in SAS version 9 (SAS Inst. Inc., Cary, NC). The comparative analysis between means was conducted using the Duncan test. Data are presented as the mean of each group and the SD (standard deviation) together with the significance levels ( $P$ value). Differences between means were considered statistically significant when $P<0.05$. Linear discriminant functions were developed using the PROC DISCRIM procedure contained in SAS version 9 to assess the suitability of tocopherol concentration for discriminating groups of different feeding backgrounds. Equations to quantify the weight gain depending on gammatocopherol in fat and muscle samples were developed using the PROC REG statement in SAS. Exponential equations were calculated using the SAS PROC NLIN procedure. The exponential response was calculated using the following equation: $y=a+b^{*} \exp ^{(-c x)}$.

\section{RESULTS}

\subsection{Alpha and Gamma-Tocopherol Quantification}

The average concentration of alpha- and gammatocopherols and the ratio gamma:alpha in fat and muscle samples of the first two years (seasons 1 and 2) according to the feeding background is presented in Table 1. Fat and muscle samples from pigs exclusively fed with acorns and grass in the forest (FREE-OUT) had the highest concentration of gamma-tocopherol $(\mathrm{P}<0.0001)$. The FREE-OUTFEED group showed intermediate gamma-tocopherol concentrations and the lowest values were found for the FEED-OUT and FEED-IN groups. The concentration of alpha-tocopherol was also higher in the fat from pigs fed in free-range conditions (FREEOUT) than the fat from pigs in the other groups $(P<0.0001)$. However, these differences between FREE-OUT and FREE-OUT-FEED were not found in the muscle. In both tissues (fat and muscle), the group fattened with a commercial diet (FEED-IN) had the lowest alpha-tocopherol concentrations when compared with the other groups $(P<0.0001)$. Intermediate alpha-tocopherol values were found in the fat and muscle from pigs in the FEED-OUT group.

\subsection{Discriminant Analysis}

The discriminant functions obtained from the tocopherol concentrations in the fat and muscle samples of these two first years are presented in Table 2, their corresponding validation in Table 3 and how the feeding groups were differentiated between them, in Figures 1 and 2. A decimal logarithm was taken for the gamma-tocopherol variable to normalize values. The $R^{2}$ was higher for the logarithm of the gamma-tocopherol than for the alpha-tocopherol variable (0.68 vs. 0.44$)$ in the linear discriminant functions for fat. In muscle samples, the proportion of gamma:alpha-tocopherol was used to improve the prediction ability and the gamma-tocopherol variable had higher $R^{2}(0.90)$ than alpha $\left(R^{2}=0.43\right)$ and the ratio between both tocopherols, gamma-alpha $\left(R^{2}=0.70\right)$. Gammatocopherol was the main compound that contributed to function 1 in the canonical discriminant functions for fat and muscle samples, while alpha-tocopherol principally contributed to function 2 .

Table 1

Gamma and alpha-tocopherol concentration in fat and muscle samples according to the feeding background obtained from seasons 1 and 2

\begin{tabular}{|c|c|c|c|c|c|c|}
\hline \multirow{2}{*}{$\mu \mathrm{g} / \mathrm{g}$ sample } & \multicolumn{3}{|c|}{ FAT } & \multicolumn{3}{|c|}{ MUSCLE } \\
\hline & $\gamma$-Tocopherol & $\alpha$-Tocopheroll & $\gamma / \alpha$ Ratio & $\gamma$-Tocopherol & $\alpha$-Tocopherol & $\gamma / \alpha$ Ratio \\
\hline FREE-OUT ${ }^{1}$ & $1.33^{a}$ & $10.87^{\mathrm{a}}$ & $0.12^{\mathrm{a}}$ & $1.12^{\mathrm{a}}$ & $7.57^{\mathrm{a}}$ & $0.15^{\mathrm{a}}$ \\
\hline FREE-OUT-FEED ${ }^{2}$ & $0.87^{b}$ & $9.16^{b}$ & $0.09^{b}$ & $0.61^{b}$ & $7.15^{\mathrm{a}}$ & $0.08^{b}$ \\
\hline FEED-OUT ${ }^{3}$ & $0.45^{c}$ & $8.90^{b}$ & $0.05^{c}$ & $0.16^{c}$ & $5.78^{b}$ & $0.03^{d}$ \\
\hline FEED-IN ${ }^{4}$ & $0.41^{\mathrm{c}}$ & $4.64^{c}$ & $0.09^{b}$ & $0.14^{c}$ & $2.48^{c}$ & $0.06^{\mathrm{c}}$ \\
\hline $\mathrm{SD}^{5}$ & 0.30 & 2.19 & 0.04 & 0.18 & 1.93 & 0.03 \\
\hline $\mathrm{P}<\mathrm{F}$ & 0.0001 & 0.0001 & 0.0001 & 0.0001 & 0.0001 & 0.0001 \\
\hline
\end{tabular}

${ }^{1}$ FREE-OUT: pigs raised in free-range conditions and exclusively fed with acorns and grass (known as bellota)

2 FREE-OUT-FEED: pigs raised in free-range conditions and fed with acorns and grass (they put on at least $29 \mathrm{~kg}$ in free conditions) and also with feed during the fattening phase (known as recebo)

${ }^{3}$ FEED-OUT: pigs fed with either a conventional feed or a fat-enriched diet and with access to grass (known as campo)

${ }^{4}$ FEED-IN: pigs fattened with a standard commercial pig feed (known as cebo).

${ }^{5}$ SD: Standard deviation. 
Table 2

Linear discriminant functions in fat and muscle samples obtained from data of seasons 1 and 2

\begin{tabular}{|c|c|c|c|c|c|c|c|}
\hline Variable & FREE-OUT $^{1}$ & FREE-OUT-FEED ${ }^{2}$ & FEED-OUT ${ }^{3}$ & FEED-IN ${ }^{4}$ & $\mathrm{SD}^{5}$ & $\mathbf{R}^{2}$ & Pr $>F$ \\
\hline \multicolumn{8}{|l|}{ Fat samples } \\
\hline Constant & -21.670 & -13.393 & -8.838 & -3.680 & & & \\
\hline loggtoc ${ }^{6}$ & 32.207 & 23.129 & 9.558 & 12.714 & 0.26 & 0.68 & $<0.0001$ \\
\hline$\alpha$-Tocopherol & 1.529 & 1.360 & 1.596 & 0.672 & 2.96 & 0.44 & $<0.0001$ \\
\hline \multicolumn{8}{|l|}{ Muscle samples } \\
\hline Constant & -39.019 & -18.818 & -7.806 & -5.552 & & & \\
\hline loggtoc 6 & 71.350 & 36.399 & -17.906 & -24.090 & 0.28 & 0.90 & $<0.0001$ \\
\hline$\alpha$-Tocopherol & 2.007 & 2.113 & 2.487 & -1.832 & 2.54 & 0.43 & $<0.0001$ \\
\hline$\gamma / \alpha$ Tocopherol Ratio & 65.221 & 66.308 & 121.740 & 148.477 & 0.06 & 0.7 & $<0.0001$ \\
\hline
\end{tabular}

${ }^{1}$ FREE-OUT: pigs raised in free-range conditions and exclusively fed with acorns and grass (known as bellota)

${ }^{2}$ FREE-OUT-FEED: pigs raised in free-range conditions and fed with acorns and grass (they put on at least $29 \mathrm{~kg}$ in free conditions) and also with feed during the fattening phase (known as recebo)

${ }^{3}$ FEED-OUT: pigs fed with either a conventional feed or a fat-enriched diet and with access to grass (known as campo)

${ }^{4}$ FEED-IN: pigs fattened with a standard commercial pig feed (known as cebo).

${ }^{5}$ SD: Standard deviation.

${ }^{6}$ loggtoc: decimal logarithm of gamma-tocopherol concentration

The validation results of the discriminant functions (Table 3 ) show that $24 \%$ of the fat samples were not correctly classified giving a $76 \%$ success rate. Moreover, $31 \%$ of the fat samples from pigs fed free-range (FREE-OUT) were assigned to the FREE-OUT-FREE group. For the group FREE-OUT-FEED, $72 \%$ of the samples were assigned to the correct feeding system however, $19 \%$ were considered as FREE-OUT, $5 \%$ as FEED-OUT and $3.5 \%$ as FEED-IN. The group with the lowest proportion of false negatives was FEEDIN with $96 \%$ correct classification, showing $2 \%$ of

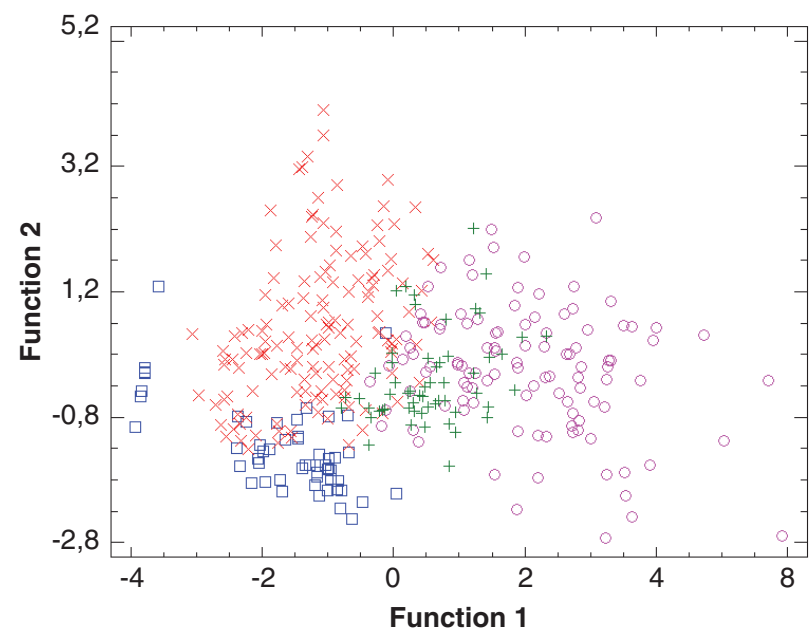

$\square$ FEED-IN $\times$ FEED-OUT O FREE-OUT + FREE-OUT-FEED

\section{Figure 1}

Canonical discriminant functions for fat samples (seasons

1 and 2) showing the relationship and distribution among

feeding systems (FREE-OUT: pigs raised in free-range

conditions with acorns and grass; FREE-OUT-FEED: pigs

raised in free-range conditions and fed with acorns and grass and also with feed during the fattening phase; FEED-OUT: pigs fed with feed and with access to grass; FEED-IN: pigs fattened with a standard commercial pig feed). the fat samples classified as FREE-OUT-FEED and $2 \%$ as FEED-OUT. However, the FEED-IN group had a high proportion of false positives $(20 \%$ that were assigned to FEED-OUT and $3.5 \%$ assigned to FREE-OUT-FEED). The FREE-OUT-FEED group had the highest proportion of false positives that were classified as FREE-OUT feeding (31.5\%), FEED-OUT (11\%) or FEED-IN (2\%).

In the muscle samples, the validation results by cross validation of the calculated discriminant functions showed that $76 \%$ of the total were correctly classified and $24 \%$ were assigned to the

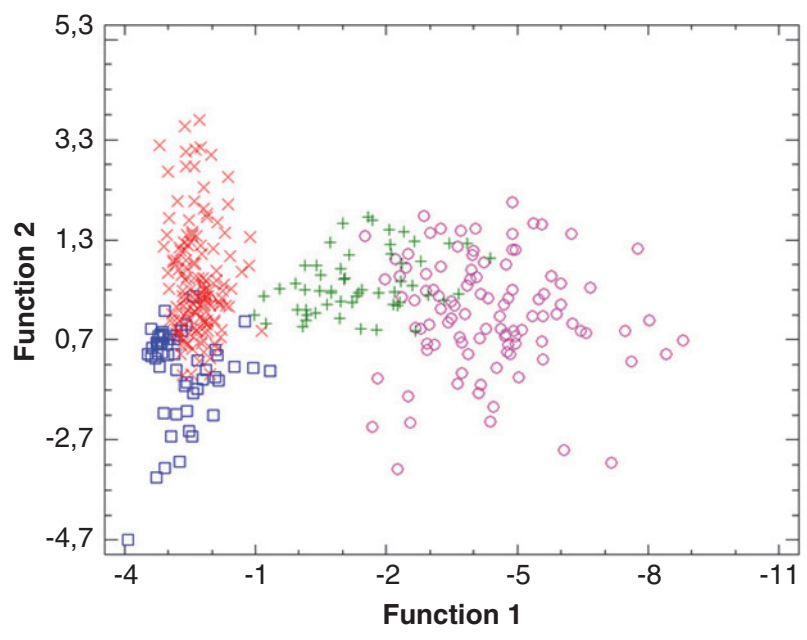

$\square$ FEED-IN $\times$ FEED-OUT O FREE-OUT + FREE-OUT-FEED

Figure 2

Canonical discriminant functions for muscle samples (seasons 1 and 2) showing the relationship and distribution among feeding systems (FREE-OUT: pigs raised in free-range conditions with acorns and grass ; FREE-OUT-FEED: pigs raised in free-range conditions and fed with acorns and grass and also with feed during the fattening phase; FEED-OUT: pigs fed with feed and with access to grass; FEED-IN: pigs fattened with a standard commercial pig feed). 
Table 3

Classification of fat and muscle samples (\% assigned correctly) from seasons 1 and 2 according to discriminant functions (cross validation)

\begin{tabular}{|c|c|c|c|c|c|}
\hline From feeding & FREE-OUT $^{1}$ & FREE-OUT-FEED ${ }^{2}$ & FEED-OUT ${ }^{3}$ & FEED-IN ${ }^{4}$ & Total (\%) \\
\hline \multicolumn{6}{|l|}{ Fat samples } \\
\hline FREE-OUT & 69 & 31 & 0 & 0 & 100 \\
\hline FREE-OUT-FEED & 19 & 72 & 5 & 4 & 100 \\
\hline FEED-OUT & 0 & 11 & 69 & 20 & 100 \\
\hline FEED-IN & 0 & 2 & 2 & 96 & 100 \\
\hline \multicolumn{6}{|l|}{ Muscle samples } \\
\hline FREE-OUT & 85 & 15 & 0 & 0 & 100 \\
\hline FREE-OUT-FEED & 11 & 84 & 5 & 0 & 100 \\
\hline FEED-OUT & 0 & 0 & 78 & 22 & 100 \\
\hline FEED-IN & 0 & 0 & 5 & 95 & 100 \\
\hline
\end{tabular}

${ }^{1}$ FREE-OUT: pigs raised in free-range conditions and exclusively fed with acorns and grass (known as bellota)

${ }^{2}$ FREE-OUT-FEED: pigs raised in free-range conditions and fed with acorns and grass (they put on at least $29 \mathrm{~kg}$ in free conditions) and also with feed during the fattening phase (known as recebo)

${ }^{3}$ FEED-OUT: pigs fed with either a conventional feed or a fat-enriched diet and with access to grass (known as campo)

${ }^{4}$ FEED-IN: pigs fattened with a standard commercial pig feed (known as cebo)

wrong feeding background. The Quantification of tocopherols in muscle for feeding discrimination seemed to be more feasible. The FREE-OUT group was correctly classified in $85 \%$ of the muscle samples, FREE-OUT-FEED in $84 \%$, FEED-OUT in $78 \%$ and FEED-IN in $95 \%$. The percentage of the muscle samples from FREE-OUT that were wrongly assigned to FREE-OUT-FEED was $15 \%$. Moreover, $11 \%$ of the samples from FREE-OUTFEED were wrongly considered as FREE-OUT and $5 \%$ as FEED-OUT. On the other hand, $22 \%$ of the muscle samples from the FEED-OUT feeding group were considered as FEED-IN and 5\% from FEED-IN as FEED-OUT.

The classification results for fat and muscle samples from season 3 according to the discriminant functions obtained from seasons 1 and 2 are presented in table 4. A high percentage of fat and muscle samples from the FREE-OUT feeding group were correctly classified (88\% for fat and $98 \%$ for muscle samples). The FEEDOUT group also had a high percentage of correct classifications ( $87 \%$ for fat and $89 \%$ for muscle). The FEED-IN group had intermediate proportions

Table 4

Classification of fat and muscle samples (\% correctly assigned) from season 3 according to calculated discriminant functions

\begin{tabular}{|c|c|c|c|c|c|}
\hline From feeding & FREE-OUT ${ }^{1}$ & FREE-OUT-FEED ${ }^{2}$ & FEED-OUT ${ }^{3}$ & FEED-IN ${ }^{4}$ & Total (\%) \\
\hline \multicolumn{6}{|l|}{ Fat samples } \\
\hline FREE-OUT & 88 & 12 & 0 & 0 & 100 \\
\hline FREE-OUT-FEED & 48 & 40 & 12 & 0 & 100 \\
\hline FEED-OUT & 0 & 0 & 87 & 13 & 100 \\
\hline FEED-IN & 4 & 0 & 32 & 64 & 100 \\
\hline \multicolumn{6}{|l|}{ Muscle samples } \\
\hline FREE-OUT & 98 & 0 & 0 & 2 & 100 \\
\hline FREE-OUT-FEED & 44 & 48 & 4 & 4 & 100 \\
\hline FEED-OUT & 0 & 11 & 89 & 0 & 100 \\
\hline FEED-IN & 2 & 11 & 22 & 65 & 100 \\
\hline
\end{tabular}

${ }^{1}$ FREE-OUT: pigs raised in free-range conditions and exclusively fed with acorns and grass (known as bellota)

${ }^{2}$ FREE-OUT-FEED: pigs raised in free-range conditions and fed with acorns and grass (they put on at least $29 \mathrm{~kg}$ in free conditions) and also with feed during the fattening phase (known as recebo)

${ }^{3}$ FEED-OUT: pigs fed with either a conventional feed or a fat-enriched diet and with access to grass (known as campo)

${ }^{4}$ FEED-IN: pigs fattened with a standard commercial pig feed (known as cebo) 
(64\% and $65 \%$ for fat and muscle, respectively) and the FREE-OUT-FEED group showed the lowest percentage of correct assignments $(40 \%$ for fat and $48 \%$ for muscle). Half of the samples from the FREE-OUT-FEED group were classified as FREEOUT-FEED ( $48 \%$ in fat and $44 \%$ in muscle) and smaller proportions were assigned to FEED-OUT (12\% in fat and $4 \%$ in muscle samples).

\subsection{Regression Equations}

Additionally, regression equations were developed to quantify the weight gained by the animals depending on the gamma-tocopherol concentration in the fat and muscle samples (Table 5). The regression equations (linear, quadratic and exponential) obtained from muscle samples had higher adjustments than those from fat $\left(R^{2}=0.69\right.$ vs. 0.60 respectively in the linear equation; $R^{2}=$ 0.81 vs. 0.62 respectively in the quadratic equation; $\mathrm{R}^{2}=0.80$ vs. 0.61 respectively in the exponential equation).

The comparison between classifications based on regression equations obtained from the tocopherol concentration of muscle to calculate weight gain and the results obtained by the discriminant functions are presented in Table 6 . A high percentage of classification coincidences were found when using linear regression equations or linear discriminant functions. Hence, $100 \%$ of the muscle samples from the group FREE-OUTFEED were classified in the same group. Moreover, there were $89 \%$ of coincidences in samples from the FREE-OUT feeding group. However, when using discriminant functions or weight gained, coincidences were lower in the FEED-OUT group. Results were similar when using the quadratic regression equations along with the linear discriminant functions with the exception of $17 \%$ of the muscle samples from FREE-OUT-FEED that were classified as FEED-IN. The application of the exponential regression equation instead of the discriminant functions was not as accurate as the other regression equations. So, coincidences for the group FREE-OUT-FEED were only of $25 \%$, while $33 \%$ of these samples were considered as FEEDOUT feeding and $42 \%$ as FEED-IN.

\section{DISCUSSION}

The feeding background affected the alpha and gamma-tocopherol concentrations. Samples from the FREE-OUT group had higher $(P<0.01)$ concentrations of gamma-tocopherol in fat and muscle than those from the FREE-OUT-FEED, FEED-OUT and FEED-IN groups. These results can be attributed to the high content of gammatocopherol in acorns, which has been previously reported (Rey et al., 1998; Rey et al., 2006a; Isabel et al., 2009; López-Carrasco et al., 2011; Tejerina et al., 2011). Since FREE-OUT-FEED pigs consumed lower amounts of acorns, they had a lower proportion of gamma-tocopherol in tissues than pigs exclusively fed free-range, but higher than pigs fed with a mixed diet indoors (FEED-IN) or those fed with a mixed diet and consuming grass outdoors (FEED-OUT). So the presence of gammatocopherol in tissues is directly related to acorn consumption. On the other hand, grass has been reported to provide tocopherol mainly in the form of alpha, while the proportion of gamma-tocopherol is much lower than in acorns (Rey et al., 1998; Rey et al., 2006b; López-Carrasco, et al., 2011; Tejerina et al., 2011). Hence, the FEED-IN group exclusively fed a mixed diet had the lowest concentration of alpha-tocopherol in muscle and fat than the other groups, while FEED-OUT and FREE-OUT-FEED groups showed intermediate values. A similar trend in the concentrations of both tocopherols has been reported before in different tissues (Rey et al., 1997; Cava et al., 2000; Rey et al., 2006a,b; Rey et al., 2010) for pigs fed in free-range conditions, with comercial feed diet, or fed during a different period in the forest. However, this is the first study examining tocopherol concentration in fat and

Table 5

Calculated equations to quantify the weight gained (arrobas) depending on gamma-tocopherol concentration $\left(\mu \mathrm{g} \mathrm{g}^{-1}\right)$ in fat and muscle (from data of seasons 1 and 2 )

\begin{tabular}{|c|c|c|c|}
\hline Adjust & Equation & $\mathbf{R}^{2}$ & $S^{a}$ \\
\hline \multicolumn{4}{|l|}{ Fat } \\
\hline Linear & weight gained $=(-0.7506)( \pm 0.1487)+3.9124( \pm 0.1701)^{\star} \mathrm{Gtoc}^{\mathrm{b}}$ & 0.60 & 1.445 \\
\hline Quadratic & weight gained $=(-1.6574)( \pm 0.2373)+6.4339( \pm 0.5493) *$ Gtoc $-1.2821( \pm 0.2664){ }^{*} \mathrm{Gtoc}^{2}$ & 0.62 & 1.402 \\
\hline Exponential & weight gained $=11.3029( \pm 2.6298)-12.7986( \pm 2.4335){ }^{*} \exp \left(\left(-0.4814( \pm 0.1849){ }^{*}\right.\right.$ Gtoc $)$ & 0.61 & 1.415 \\
\hline \multicolumn{4}{|l|}{ Muscle } \\
\hline Linear & weight gained $=(0.0375)( \pm 0.0946)+4.1412( \pm 0.1439)^{*} \mathrm{G}$ toc & 0.69 & 1.245 \\
\hline Quadratic & weight gained $=(-0.9501)( \pm 0.0972)+9.4029( \pm 0.3568) *$ Gtoc $-3.5516( \pm 0.2286){ }^{*}$ Gtoc $^{2}$ & 0.81 & 0.9685 \\
\hline Exponential & weight gained $=5.0993( \pm 0.2144)-5.0012( \pm 0.3261){ }^{*} \exp \left(\left(-2.5160( \pm 0.4691){ }^{*} \mathrm{Gtoc}\right)\right.$ & 0.80 & 0.9946 \\
\hline
\end{tabular}

\footnotetext{
a SD: Standard deviation
}

${ }^{\mathrm{b}}$ Gtoc: gamma-tocopherol concentration 
Table 6

Comparison of classification according to discriminant functions and weight gained equations in muscle samples from campaign 3 (\% assigned)

\begin{tabular}{|c|c|c|c|c|c|}
\hline $\begin{array}{l}\text { From weight } \\
\text { classification }\end{array}$ & FREE-OUT ${ }^{1}$ & FREE-OUT-FEED ${ }^{2}$ & FEED-OUT ${ }^{3}$ & FEED-IN ${ }^{4}$ & Total (\%) \\
\hline \multicolumn{6}{|c|}{ Classification coincidences based in averaged weight gained (linear equation) } \\
\hline FREE-OUT & 89 & 10 & 0 & 2 & 100 \\
\hline FREE-OUT-FEED & 0 & 100 & 0 & 0 & 100 \\
\hline FEED-OUT & & & & & 100 \\
\hline FEED-IN & 0 & 12 & 49 & 39 & 100 \\
\hline \multicolumn{6}{|c|}{ Classification coincidences based on averaged weight gained (quadratic equation) } \\
\hline FREE-OUT & 89 & 10 & 0 & 2 & 100 \\
\hline FREE-OUT-FEED & 0 & 83 & 0 & 17 & 100 \\
\hline FEED-OUT & & & & & 100 \\
\hline FEED-IN & 0 & 7 & 53 & 40 & 100 \\
\hline \multicolumn{6}{|c|}{ Classification coincidences based on averaged weight gained (exponential equation) } \\
\hline FREE-OUT & 83 & 15 & 0 & 2 & 100 \\
\hline FREE-OUT-FEED & 0 & 25 & 33 & 42 & 100 \\
\hline FEED-OUT & & & & & 100 \\
\hline FEED-IN & 0 & 0 & 65 & 35 & 100 \\
\hline
\end{tabular}

${ }^{1}$ FREE-OUT: pigs raised in free-range conditions and exclusively fed with acorns and grass (known as "bellota")

${ }^{2}$ FREE-OUT-FEED: pigs raised in free-range conditions and fed with acorns and grass (they put on at least $29 \mathrm{~kg}$ in free conditions) and also with feed during the fattening phase (known as "recebo")

${ }^{3}$ FEED-OUT: pigs fed with either a conventional feed or a fat-enriched diet and with access to grass (known as "campo")

${ }^{4}$ FEED-IN: pigs fattened with a standard commercial pig feed (known as "cebo")

muscles from pigs fed with a mixed diet and with access to grass outdoors (FEED-OUT). This group which is known as "campo" was included in the latest quality policy for the Iberian pig (BOE, 2007) but no information was available concerning the alpha and gamma-tocopherol concentrations of this group or a comparison with the other groups in order to establish its correct classification.

Concerning the quantified concentration of gamma and alpha tocopherols of the present study, values were similar to those reported before (Rey et al., 2006 a,b; Daza et al., 2005), in this type of muscle obtained by direct extraction with differences probably due to variations in acorn and grass consumption, composition, or the delay until analyses were carried out (Rey et al., 2010). However in fat, the gamma-tocopherol concentrations of the present study were lower than those reported in previous studies (Rey et al., 2006a, 2006b, Rey et al., 2010), due not only to the same variations as in muscle but also in part to small modifications of the analytical procedure which allowed for a more accurate quantification of gamma-tocopherol.

When discriminant functions were developed from the tocopherol concentration of fat and muscle samples to differentiate the feeding background (Table 2), a better fit for gamma-tocopherol was observed than for alpha-tocopherol. A previous study reported closer relationships among the days of free-range or weight gained and the concentration of gamma-tocopherol (Rey et al., 2006b), which is again related with the high content of gammatocopherol found in acorns. Moreover, the canonical discriminant functions (Figures 1 and 2) that represented how feeding groups were differentiated between them showed that function 1, which mainly considered gamma-tocopherol concentration, separated samples from FEED-IN or FEED-OUT and FREE-OUT or FREE-OUT-FEED. Meanwhile, alpha-tocopherol (mainly considered in Function 2) separated the group FEED-IN from the others. In the present study it is also of interest to observe that even though the percentage of total classification errors in muscle and fat samples were similar (24\%), muscle seemed to have higher predictive ability as demonstrated by the higher percentage of samples classified into the correct feeding group and the lower proportion of false positives and negatives in the cross validation analysis for this tissue (Table 3 ). Moreover, the gamma-tocopherol variable obtained from muscle samples of the first two years to develop linear discriminant functions showed higher $R^{2}$ values than in fat $\left(R^{2}=0.90\right.$ vs. 0.68) (Table $2)$. There is no other information in the literature concerning the feasibility of alpha and gammatocopherol discriminant analysis for classifying pig samples according to their feeding background. So, this information is of importance for the Iberian pig production and quality sector. 
In order to corroborate the feasibility of the discriminant equations in practical situations, they were applied to a group of blind samples obtained during the third year (Table 4). Prediction ability was again superior for muscle discriminant functions than for those obtained from fat samples. Muscle samples from pigs fed free-range were almost totally correctly classified ( $98 \%)$, while some of the fat samples from this feeding group (FREEOUT) were assigned as FREE-OUT-FEED (12\%). In both tissues, the group with highest number of classification errors was FREE-OUT-FEED in which $48 \%$ of fat samples and $44 \%$ of muscle samples were classified in the FREE-OUT group. The incorrect classification of FREE-OUT-FEED pigs as FREE-OUT and vice versa was also observed in the cross validation of the discriminant functions with data from seasons 1 and 2 . This would indicate that based on the alpha and gamma-tocopherol content of these samples, both feeding groups could be considered of similar quality. So, even though pigs from free-range feeding have to put on at least 4 arrobas in the forest, while pigs from FREE-OUT-FEED group need to reach at least 2,5 arrobas (BOE, 2007), when the pigs' weight gain got close to the lower or upper established limits, the correct feeding classification may be difficult to achieve (Figures 1 and 2). Moreover, interactions between these two feeding groups (FREE-OUT and FREE-OUT-FEED) could be explained by individual differences in the intake of either acorns or grass or by their variable composition. Hence, Tejerina et al. (2011) and López-Carrasco et al. (2011) reported differences in gamma- and alphatocopherol concentrations of acorns and grass with maturation time and so with the month of free-range feeding. Moreover, López-Carrasco et al. (2011) have described that the holm oak tree and its location in the forest can also have an influence on the gamma-tocopherol concentration of acorns. Moreover, the metabolic accumulation of tocopherols may be affected by differences in the consumption of one or the other because the uptake of tocopherol isoforms seems to be different (Ikeda et al., 2001).

It is also of interest to note that $32 \%$ of fat and $22 \%$ of muscle samples were wrongly classified as FEED-OUT instead of FEED-IN during the third season (table 4). The interaction between these two groups was also observed in the cross validation of the discriminant functions for seasons 1 and 2 (Table 3). The FEED-OUT and FEEDIN groups mainly differed in the concentration of alpha-tocopherol because the concentration of gamma-tocopherol was similar. Taking into account that alpha-tocopherol content depends on the alpha-tocopherol levels in the feed, classification errors between these two feeding groups could be mainly explained by differences in either grass intake (affected by environmental factors), or the alpha-tocopheryl acetate supplementation of feeds. Hence, a range of values from 2.2 to $3.8 \mu \mathrm{g} \mathrm{g}^{-1}$ of alpha-tocopherol were reported in muscle from
Iberian pigs after a supplementation of $10 \mathrm{mg}$ alpha-tocopheryl acetate $\mathrm{kg}^{-1}$ or $125 \mathrm{mg} \mathrm{kg}^{-1}$ in feed (Rey et al., 1997). On the other hand, Daza et al. (2005) found that the muscles from Iberian pigs fed with diets supplemented with alpha-tocopheryl acetate up to $260 \mathrm{mg} \mathrm{kg}^{-1}$ contained average values of $4.4 \mathrm{\mu g} \mathrm{g}^{-1}$ and these alpha-tocopherol levels were similar to those from pigs fed on acorns and grass. However, Ventanas et al. (2006) found lower alpha-tocopherol concentrations in the muscle from pigs fed on natural resources than those supplemented with $250 \mathrm{mg} \mathrm{kg}^{-1}$ in feed. Differences in alpha-tocopherol accumulation in tissues and the interaction between FEED-OUT and FEED-IN groups or to a smaller extent with other groups could also be affected by variations in the tocopherol composition depending on the type of grass as a function of the predominant species (Mutetika and Mahan, 1993; Lynch et al., 2001) and the date or year (López-Carrasco et al., 2011; Tejerina et al., 2011). Mutetikka and Mahan (1993) have reported alpha-tocopherol values in grass of between 29 to $100 \mathrm{mg}$ of alpha-tocopherol kg-1 DM; other authors found levels of $158.3 \mathrm{mg} \mathrm{kg}^{-1} \mathrm{DM}$ (Rey et al., 2006b) and $276 \mathrm{mg} \mathrm{kg}^{-1} \mathrm{DM}$ (Isabel et al., 2009).

Finally, taking into account that the feeding classification established by the Spanish legislation is in part dependent on the minimum weight gained during the fattening phase (4 arrobas in free-range group; 2,5 arrobas in pigs fed in freerange and with a mixed diet feed; and 0 arrobas in pigs fed exclusively with a mixed diet), and the relationship previously observed (Rey et al., $2006 \mathrm{~b}$ ) between the weight gained and the gammatocopherol concentration, regression equations were calculated (Table 5). Again, muscle samples showed better fit than the fat $\left(R^{2}=0.81\right.$ vs. 0.62 for quadratic equation; $\mathrm{P}<0.0001)$. Moreover, a higher quadratic adjustment than linear $\left(R^{2}=0.81\right.$ vs. 0.69$)$ was found in muscle while in fat these were similar $\left(R^{2}=0.62\right.$ vs. 0.60). Previous calculated regression equations (Rey et al., 2006b) showed a saturation effect in muscle but not in subcutaneous fat. When classifications of muscle samples from the last season according to the discriminant functions and weight gained equations were compared (Table 6), a high percentage of similarities were found. It is interesting to point out that because the FEED-OUT classification was not obtained by the regression equations, this group of samples was classified as FEED-IN. So, the three groups (FREE-OUT, FREE-OUT-FEED, and FEED-IN) had a percentage of coincidences higher than $83 \%$ by discriminant functions and regression equation (linear and quadratic) classification. There is no other information in the literature concerning the feasibility of using alpha and gamma-tocopherol concentrations for classification according to the feeding background. To our knowledge, there is a single previous study in which the relationship between gamma-tocopherol and weight gained was reported and regression equations were calculated 
(Rey et al., 2006b) but this study was carried out in experimental situations where the groups of pigs were of the same origin and genetics and $(n=10$ 11) fed in a single geographical location (Oropesa, Toledo). So the results obtained in the present study, which takes into account the heterogeneity of the Iberian pig sector, are more applicable to discriminating the feeding background in practical situations.

\section{CONCLUSIONS}

In conclusion, the quantification of gamma and alpha-tocopherol in the fat or muscle of Iberian pigs is a useful method to discriminate the feeding background of the animals and permitted a successful classification in $76 \%$ of cases (either by linear discriminant functions or regression equations) into the four qualities defined by the Spanish Quality Policy for the Iberian Pig. Quantification in muscle seemed to be more accurate than in fat and resulted in a lower number of false negatives and positives. Merging of the categories to three (the groups of pigs fed with feed "cebo" and access to grass "campo" as a unique category) may allow for improving the accuracy of the classification using gamma and alpha-tocopherol quantification to $89 \%$ of cases. When the feeding categories are reduced to two: 1) pigs fed with acorns and grass independently of the weight gained (4 or 2,5 arrobas) and 2) pigs fed with feed (without or with access to grass) a 98\% success rate could be achieved in classification using gamma and alpha-tocopherol concentration determination. This information contributes to a great extent to the correct classification of the Iberian pig meat and products in practical situations.

\section{ACKNOWLEDGEMENTS}

This research was supported by the coordinate project INIA-RTA2008-00026.

\section{REFERENCES}

BOE 2001. RD 1083/2001, de 5 de octubre. Norma de Calidad para el jamón ibérico, paleta ibérica y caña de lomo ibérico elaborados en España. Spain.

BOE 2007. RD. 1469/2007, de 2 de noviembre. Norma de Calidad para la carne, el jamón, la paleta y la caña de lomo ibéricos. Spain.

Cantos E, Espín JC, López-Bote C, Ordóñez JA, TomásBarberán FA. 2003. Phenolic compounds from quercus spp. Acorns, the main dietary constituent of Iberian pigs raised extensively. J. Agric. Food Chem. 51, 6248-6255

Cava R, Ventanas J, Tejeda JF, Ruiz J, Antequera T. 2000. Effect of free-range rearing and -tocopherol and copper supplementation on fatty acid profiles and susceptibility to lipid oxidation of fresh meat from Iberian pigs. Food Chem. 68, 51-59.
Daza A, Rey Al, Ruiz J, Lopez-Bote CJ. 2005. Effects of feeding in free-range conditions or in confinement with different dietary MUFA/PUFA ratios and $\alpha$-tocopheryl acetate, on antioxidants accumulation and oxidative stability in Iberian pigs. Meat Sci. 69, 151-163.

García C, Ventanas J, Antequera T, Ruiz J, Cava R, Alvarez P. 1996. Measuring sensorial quality of Iberian ham by Rasch model. J. Food Qual. 19, 397-412.

Ikeda S, Toyoshima K, Yamashita K. 2001. Dietary sesame seeds elevate $\alpha$ - and $\gamma$-tocotrienol concentrations in skin and adipose tissue of rats fed the tocotrienol-rich fraction extracted from palm oil. $J$. Nutr. 131, 2892-2897.

Isabel B, Cordero G, López-Bote CJ, Daza A. 2009. Tocopherol content, weight loss and instrumental colour analysis of Iberian dry-cured ham as affected by rearing and feeding systems. Grasas Aceites 60, 248-254.

Lynch A, Kerry JP, Buckley DJ, Morrissey PA, López-Bote C. 2001. Use of high pressure liquid chromatography (HPLC) for the determination of $\alpha$-tocopherol levels in forage (silage/grass) samples collected from different regions in Ireland. Food Chem. 72, 521-524.

López-Bote CJ. 1998. Sustained utilisation of the Iberian pig breed. Meat Sci. 49, S17-S27.

López-Carrasco C, Rey AI, Daza A, López-Bote C. 2011. Composición en ácidos grasos y tocoferoles de la bellota de encina den el CIA Dehesón del Encinar, Toledo. Reunión científica de la SEEP, 1st ed, Toledo pags 573-578.

López-Carrasco C, Rey AI, Daza A, López-Bote C. 2011. Composición en ácidos grasos y tocoferoles del pasto herbáceo de otoño en una dehesa toledana. Reunión científica de la SEEP, 1st ed, Toledo pags 579-584.

Mutetikka DB, Mahan DC. 1993. Effect of pasture, confinement and diet fortification with vitamin $E$ and selenium on reproducing gilts and their progeny. $J$. Anim. Sci. 71, 3211-3218.

Pugliese C, Sirtori F. 2012. Quality of meat and meat products produced from southern European pig breeds. Meat Sci. 90, 511-518.

Rey A, López-Bote CJ, Soares J, Isabel B. 1996. Determination of $\alpha$-tocopherol in pork with high intramuscular fat content. Grasas Aceites 47, 331-334.

Rey Al, Lopez-Bote CJ, Sanz Arias R. 1997. Effect of extensive feeding on $\alpha$ - tocopherol concentration and oxidative stability of muscle microsomes from Iberian pigs. Anim. Sci. 65, 515-520.

Rey Al, Isabel B, Cava R, López-Bote CJ. 1998. Dietary acorns provide a source of gamma-tocopherol to pigs raised extensively. Can. J. Anim. Sci. 78, 441-443.

Rey Al, Daza A, Lopez-Carrasco C, Lopez-Bote CJ. 2006a. Feeding Iberian pigs with acorns and grass in either free-range or confinement affects the carcass characteristics and fatty acids and tocopherols accumulation in longissimus dorsi muscle and backfat. Meat Sci. 73, 66-74.

Rey A, Daza A, López-Carrasco C, López-Bote CJ. 2006b. Quantitative study of the alpha- and gammatocopherols accumulation in muscle and backfat from lberian pigs kept free-range as affected by time of free-range feeding or weight gain. Anim. Sci. 82: 901908.

Rey Al, López-Bote, CJ, Daza A, Lauridsen C. 2010. Accumulation and evolution of tocopherols in dry-cured hams from Iberian pigs as affected by their feeding and rearing system. Food Chem. 123, 1170-1175.

SAS. 1999. Statistics. In: SAS Use'r guide. Statistical Analysis System Inst. Inc., Cary, NC. 
Tejerina D, García-Torres S, Cabeza de Vaca M, Vázquez FM, Cava R. 2011. Acorns (Quercus rotundifolia Lam.) and grass as natural sources of antioxidants and fatty acids in the "montanera" feeding of Iberian pig: Intraand inter-annual variations. Food Chem. 124, 997-1004.

Tejerina D, García-Torres S, Cabeza de Vaca M, Vázquez FM, Cava R. 2012. Effect of production system on physical-chemical, antioxidant and fatty acids composition of Longissimus dorsi and Serratus ventralis muscles from Iberian pig. Food Chem. 133, 293-299.

Ventanas S, Estevez M, Tejeda JF, Ruiz J. 2006. Protein and lipid oxidation in Longissimus dorsi and dry cured loin from Iberian pigs as affected by crossbreading and diet. Meat Sci. 72, 647-655.

Recibido: 9/10/12 Aceptado: $26 / 1 / 13$ 